\title{
飽和砂地盤の動的有効応力解析の簡易手法
}

\section{A SIMPLIFIED METHOD FOR DYNAMIC EFFECTIVE STRESS ANALYSIS OF SATURATED SAND DEPOSITS}

\author{
兵 動 正 幸* ・山 内 豊 聡** ・橋 詰 順一郎*** \\ By Masayuki HYODO, Toyotoshi YAMANOUCHI and Junichiro HASHIZUME
}

\begin{abstract}
Presented is a simplified procedure for performing the dynamic effective stress analysis. The proposed method is an extension of the method of equivalent linear dynamic response analysis which has been used in the total stress analysis. It is assumed, in this method, that the variations of the shear modulus and damping factor due to the magnitude of strain and reduction of effective stress are independent each other. That is, at first, the total stress analysis is done in order to obtain the shear moduli and damping factors corresponding to the specified strains, called effective strains. Secondly, the effective stress analysis is carried out and the modui are varied due to the variation of the effective stress only. In this way, by applying the simplified stress-strain relation to the effective stress analysis, it becomes possible to reduce plenty of calculating time of the effective stress analysis.
\end{abstract}

\section{1. まえがき}

従来，一般に液状化の検討といえば，地表面における 地震波の最大加速度から地中のせん断応力を類推し, 室 内実験で得られたその地盤の液状化抵抗と比較して, 液 状化の可能性を論ずるものであった ${ }^{1-4 !}$.このような考 え方は, 現行の耐震設計指針 ${ }^{51}$ にも取り入れられ, 種々 の地盤条件や地震規模に応じて評価できるように，実務 上の対応が可能な形としてまとめられている．しかしな がら,この方法では, 液状化に至るまでの過渡的な地盤 挙動を調べることはできず, 液状化過程における地中構 造物などの耐震性を正しく評価することができない。

近年になって, 液状化過程を表現し得る解析法として 有効応力解析法が開発され, 種々の構成式を用いて解析 が行われるようになった ${ }^{-10)}$. 現在もこれに類する研究 がかなり活発になされているが,この種の方法の今日に おける問題点は, 解析に用いられる動的な構成式がまだ 完全なものとはいいがたく,またあらゆる砂質土に適用

*正会員 工博 東海大学助教授 福岡校舎 ( ₹811-41 宗像市大字田久)

** 正会員 工博 九州大学教授 工学部水工土木学科 ( ₹812 福岡市東区箱崎 6-10-1)

*** 正会員 工修 九州大学大学院（現・绯日本銅管技術研 究所) ( $5514-03$ 津市雲出銅管町 1 )
可能という検証も乏しいことである.さらに，新潟地震 以来今日まで，多方面で実験が行われ蓄積されてきた， いわゆる液状化抵抗を表わす奏験データが，この種の構 成式においては全く役に立たないことも現実と隔たりを 感じさせる問題点の一因であろう。また，これまでには, 構成式によらず記実験データを用いた方法も示されて いるが, 現在行われている有効忍力解析法は, 非線形の 応答解析を要するため, 操作が難しく膨大な計算量を伴 うことも実用に支障を及ぼすものと思われる。

このような有効心力解析法が，実務設計等実用に供さ れるようになるためには，次のような条件が必要である と思われる．まず，あらゆる地盤について，さまざまな 初期条件に対して適用が叮能であること, そして計算が 比較的簡単であることなどであろうと考えられる。

本論文は, このような点を踏まえ, 有効応力法の特長 を生かしながら，手法の一般化亡簡易化を目指したもの である。すなわち、種々の地盤条件への対応を容易にす るために，液状化を表わす実験結果として，最も表現が 一般的であり,デー夕量も豊䈏な, 液状化抵抗・繰返し 回数関係を用いている.さらに, 有効応力法における計 算量を減ずるために，間隙水圧の評価回数を減らし，か つ応力・ひずみ関係の単純化をはかっている．ここでは 全応力法で用いられている等価線形化法の概念を有効応 
力法に適用することにより, 計算時間の大幅な短縮を可 能とし, より自由度の高い 2 次元問題への挔張も容易な ものにしている，なお，本解析では地震継続時間中の間 隙水圧の消散は小さいものとみなしてこれを考慮してい ない。

\section{2. 地盤の材料非線形性の評価}

繰返し載荷時の土の応力・ひずみ曲線は, 応力・ひず み関係の非線形性とエネルギー消散についてのメカニズ ムを表わしている. 土の非線形挙動を数式化しモデル化 する試みは，これまでに数多く行われいくつかのモデル が提案されているが, 土の剛性と強度を少ないパラメー ターでうまく表現できるとして Hardin-Drnevich モデ ル"1がよく使われている，また，同モデルでは，态力が ひずみの関数形として与えられていることも，一般の忘 答解析においては，使用上有利な点である. HardinDrnevich モデルは, 本来骨格曲線のみが定義され定式 化されたものであるが，これを基準として Masing 則に 従う非線形ループを表現すると次式のようになる.

$$
\tau-\tau_{a}=\frac{G_{0}\left(\gamma-\gamma_{a}\right)}{1+\left|\frac{\gamma-\gamma_{a}}{n \gamma_{r}}\right|} .
$$

ここに, $G_{0}$ は初期せん断岡性率, $\left(\gamma_{a}, \tau_{a}\right)$ は折り返し 点の座標（ただし，骨格曲線の場合は， $\left.\gamma_{a}=\tau_{a}=0\right), n$ は骨格曲線と履歴曲線を判別する指数 $(n=1:$ 骨格曲 線, $n=2:$ 履歴曲線)， $\gamma_{r}$ は規準ひずみ $\left(\gamma_{r}=\tau_{f} / G_{0}\right.$, $\tau_{s}$ : せん断強さ) である. 本解析では, 态力・ひずみ関 係としてこの双曲線モデルを用いた。

式（1）の初期接線係数は, 地盤の微小ひずみ域にお ける剛性率を表わすが，これは次に示されるRichart の 式年により求めた。

$$
\left.G_{0}=3300 \frac{(2.97-e)^{2}}{1+e} \sqrt{\sigma_{m}^{\prime}} \text { (単位 }: \mathrm{kN} / \mathrm{m}^{2}\right) \text {. }
$$

ここに, $\sigma_{m}^{\prime}$ は平均有効主応力, $e$ は間隙比である.式 ( 2) は, 有効応力の平方根に比例する関数形で表わされてお り, 初期には地盤の深さ方向へのせん断剛性率の分布形 状を放物線状に与えるが, 液状化過程における有効応力 の変動に従い修正される，すなわち，有効応力変化率の 平方根の割合で $G_{0}$ が変化していくことになる．また， せん断強さ $\tau_{s}$ は次式で表わされるが, これは有効応力 に比例して変化することになる。

$$
\tau_{f}=\frac{\sigma_{v}^{\prime}}{2} \sqrt{\left(1+K_{0}\right)^{2} \sin ^{2} \phi-\left(1-K_{0}\right)^{2}} \text {. }
$$

ここに， $\sigma_{v}^{\prime}$ は鉛直有効応力， $K_{0}$ は静止土圧係数， $\phi$ は せん断抵抗角である.

\section{3. 間隙水圧上昇量の算定方法}

間隙水圧上昇量の算定には, 非排水繰返しせん断試験

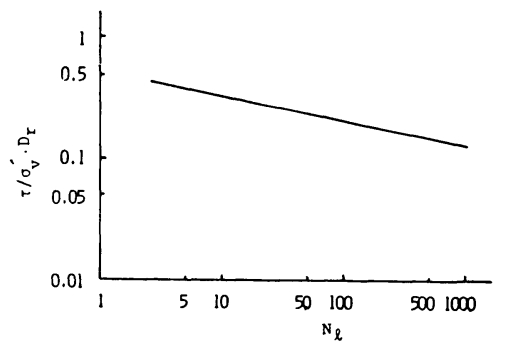

図一1 液状化に至るに必要な応力比繰返し回数関係

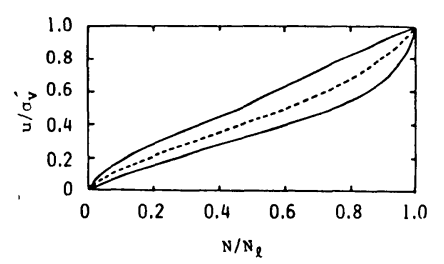

图一2 液状化過程における間隙水圧上昇径路 (Seed ら ${ }^{151 に よ る) ~}$

より得られる図一1，2の関係をそれぞれ使用した．図 -1 は, 液状化を起こすに必要な応力比と繰返し回数の

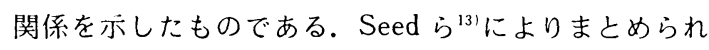
た単純せん断試験結果を両対数図上に表わすと図のよう に直線化が可能である，さらに，所定の繰返し回数で液 状化に至らしめる忘力比の大きさは，特に密な状態を除 けば相対密度に比例することが知られているので, 相対 密度で規準化し定式化すると次のようになる。

$$
N_{l}=\frac{0.038}{\left(\frac{\tau}{\sigma_{v}^{\prime} D_{r}}\right)^{4.97}}
$$

相対密度が $80 \%$ 程度を超えた密詰め状態では，この比 例関係が成り立たないことが指摘されている(14)ので, 式 （4）の適用範囲は相対密度 $80 \%$ 以下と考えるのが妥 当亡思われる. 図一2 は，非排水試験時の間隙水圧上昇 を表わすものであるが, Seed ら ${ }^{151}$ により次のような定 式化が行われている.

$$
\frac{u}{\sigma_{v}^{\prime}}=\frac{2}{\pi} \sin ^{-1}\left(\frac{N}{N_{l}}\right)^{\frac{1}{2 \delta}}
$$

ここに, $u$ は過剩間隙水圧, $\delta$ は曲線の形状を規定する 係数（図中の破線の場合 $\delta=0.7 ）$ である. 現在まで, 液状化の実験結果はこれらの形でまとめられており， 種々の砂および初期状態についてのデー夕の蓄積もなさ れている.さまざまな問題に対して, それぞれの場合に 応じて, 式 (4)，（5）の係数を調整することにより対 応が呵能である。

いま，土中に図一3に示されるようなせん断忍力の波 が作用する場合を考える. 波形はランダムであっても， 間隙水圧の上抙は波が時間軸を横切るごとに生ずるもの 


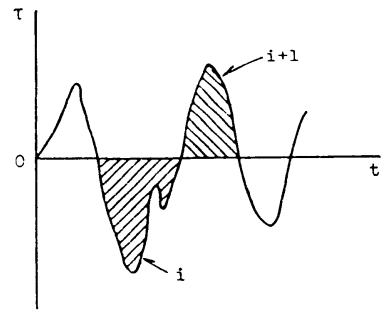

図一3 土中のせん断応力概念図

とする，すなわち，間隙水圧の評価に対しては，時間軸 で区切られた1つ1つの波が対象となり，これらはそれ ぞれの大きさをもった応力の半サイクル成分ととらえる ことができる. 発生する間隙水圧の大きさは, 半サイク ル内でのせん断応力の最大值により決定されるものとす る. 図一3において, 最初から数えて $i$ 番目の半サイク ルの波の最大值を $\tau_{i}$ とし，この大きさの波が一様に作 用した場合，液状化を起こすに必要なサイクル数を $N_{l i}$ とすると,この $N_{l i}$ は式（4）より計算される。この大 きさの态力の 1 サイクルの作用に対して, 式 (5) にお ける $N / N_{l}$ の值が， $1 / N_{l i}$ だけ增加するものと仮定する と, 半サイクルの応力の作用に対しては $1 / 2 N_{l i}$ だけ増 加が考えられる.したがって，第 1 番目から第 $m$ 番目 までの半サイクルの応力の作用に対して,

$$
\frac{N}{N_{l}}=\sum_{i=1}^{m}\left(\frac{1}{2 N_{l i}}\right)
$$

となり，これを式（5）に代入することにより任意の半 サイクル終了時点における間隙水圧が算定される．この ようにして半サイクルの応力変動ごとに間隙水圧が計算 され，それに応じてせん断剛性率およびせん断強さが低 下する．各半サイクルで生じた間隙水圧は，次の半サイ クルにおいてこれらの値を低下させるものとし，半サイ クル内での変動はないものとする.

\section{4. 有効応力法}

\section{（1）非線形解析法}

ここで取り扱う非線形有効応力解析手法は, 他の同種 の解析法に比べると，計算がいくぶん簡易である．すな わち, 他の有効応力解析法のほとんどが, それぞれの構 成式を用いて各時間ステップごとに有効忘力の変動もし くは間隙水圧の上昇を計算する仕組みになっているのに 対し, 本解析法では, 前節の間隙水圧算定方法に従い応 力の半サイクルごとに間隙水圧の発生量が計算される.

したがって，本法では半サイクル内の時間ステップにお いては有効応力の変動はなく, 普通の非線形解析が行わ れているだけである.

ここで用いる運動方程式は次に示すとおりである.

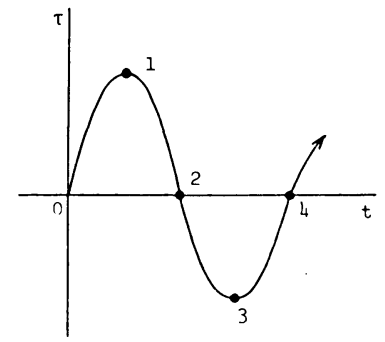

(a) 応力・時間関係

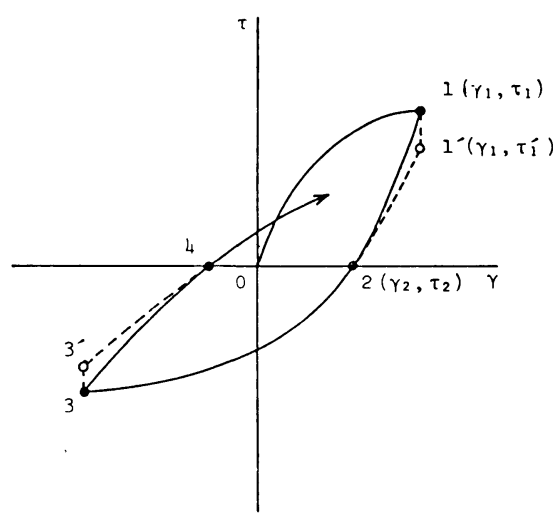

(b) 応力・ひずみ関係

図一4 非線形解析における㐫力・ひずみ概念図

ここに, $M, C, K$ はそれぞれ質量, 減衰, 剛性マトリッ クス, $\boldsymbol{u}$ は地盤の変位ベクトルである. 剛性マトリック ス $\boldsymbol{K}$ において応力・ひずみ関係の非線形性が考慮され るので，接線剛性 $\boldsymbol{K}_{t}$ を用いることにより式（7）の $\boldsymbol{K} \boldsymbol{u}(t)$ は以下のように増分型で表わされる.

$\boldsymbol{K} \boldsymbol{u}(t)=\boldsymbol{K}_{t} \boldsymbol{\Delta} \boldsymbol{u}(t)+\boldsymbol{R}(t-\Delta t)$

ここに, $\boldsymbol{R}(t-\Delta t)$ は内部の抵抗力のベクトルであり, 前回の積分ステップにおける応力から計算される. 式 （７）は直接積分法により，各時間ごとに積分される. この式では, 減衰は, せん断ひずみの履歴による履歴減 衰と速度に依存する粘性減衰が評価されるが, 計算では 粘性減衰マトリックス $C$ は省略している.

有効応力の変動を伴う土中要素のせん断応力・ひずみ 関係は，以下のようになるものと考える．図一4に，土 中要素の応力・時間および応力・ひずみ関係の概念図を 示している．まず，原点を出発する応力・ひずみ曲線は 骨格曲線となり，式（1）を用いて，

$$
\tau=\frac{G_{0} \gamma}{1+\left|\frac{\gamma}{\gamma_{r}}\right|}
$$

で表わされる.ピーク1のひずみおよび㐫力を $\left(\gamma_{1}, \tau_{1}\right)$ とすれば，これを起点とする除荷の曲線は履歴曲線とな $\eta$ 


$$
\tau-\tau_{1}=\frac{G_{0}\left(\gamma-\gamma_{1}\right)}{1+\left|\frac{\gamma-\gamma_{1}}{2 \gamma_{r}}\right|}
$$

となる。この曲線が $\gamma$ 軸を横切るとき，すなわち 2 に おいて，最初の半サイクルは終了したとみなされ，前節 の方法により間隙水圧上昇量が算出される.したがって, 次の半サイクルでは有効応力の低下を伴い, 式 (10) 中 のせん断剛性率 $G_{0}$ は式（2）により修正される。ここ で修正された新しいせん断剛性率を $G_{0}^{\prime}$ とする．2にお いて曲線の接線勾配か変化するが，このような曲線はも はや式 (10) で表わすことが不可能となり次式が導入さ れる.ただし 2 におけるひずみと応力を $\left(\gamma_{2}, \tau_{2}\right)$ とする.

$$
\tau-\tau_{1}^{\prime}=\frac{G_{0}^{\prime}\left(\gamma-\gamma_{1}\right)}{1+\left|\frac{\gamma-\gamma_{1}}{2 \gamma_{r}^{\prime}}\right|}
$$

ここに,

$$
\tau_{1}^{\prime}=\tau_{2}-\frac{G_{0}^{\prime}\left(\gamma_{2}-\gamma_{1}\right)}{1+\left|\frac{\gamma_{2}-\gamma_{1}}{2 \gamma_{r}^{\prime}}\right|}
$$

式（11）は 1'を起点とした履歷曲線とみなされ，2に おける $G_{0}$ の変化と応力, ひずみの連続条件に対処した ものである，さらに，曲線は 3 において $G_{0}^{\prime}$ の接線勾配 で折り返し，4でひずみ軸を横切るに伴い再び閒隙水圧 の上昇が評価され，以下同樣の手順となる.

\section{（2）等価線形解析法}

有効応力解析において計算量を減ずるための最も有効 な手段は, 応力・ひずみ関係を単純化することであると 思われる.ここで, Hardin-Drnevich モデルに基づく双 曲線型の応力・ひずみ曲線に代わり，原点と曲線上の点 とを結んだ割線を用いて表わしてみる。つまり応力・ひ ずみ関係を直線で近似し，各時間ステップでの剛性率の 変動を避けるのがその目的である。このような方法は等 価線形解析法と呼ばれている，本法は，従来全応力法で 用いられてきた等価線形解析法を有効応力法へ拡張する ことを試みたものであるが，その方法は以下のとおりで ある。

等価線形解析において，応力・ひずみ関係を規定する 腩性率の主な支配要因は, 有効応力とひずみレベルであ るが、本法ではそれらによる剛性率への影響はそれぞれ

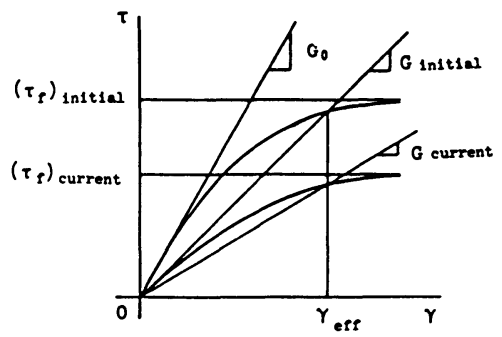

图一5 等価線形解析における応カ・ひずみ概念図
独立であるという仮定を設ける。本法における忍力・ひ ずみ関係の概念を図一 5 に示す。まず，初期の接線係数 $G_{0}$ 之減衰定数 $h$ を与えて全応力解析を行い，忘答せん 断ひずみの大きさに忍じた剛性率および減衰定数を決定 する。これらの定数が続いて行われる有効念力解析の初 期定数となる。このときの剛性率を $G_{\text {initial }}$ とすると, 式（1）を用いて,

$$
G_{\text {initial }}=\frac{G_{0}}{1+\frac{\gamma_{\text {eff }}}{\gamma_{r}}}
$$

となる、ここに， $\gamma_{\text {eff }}$ は有効せん断ひずみであり，最大 态答せん断ひずみにより決定される．次に有効応力解析 を行うが，剛性率および減衰定数はその後ひずみによる 変動はないものとし, 有効忍力の変動のみによって変化 させる.間隙水圧の上萛が生じた現時点の剛性率を $G_{\text {current }}$ とすると,

$$
G_{\text {current }}=\frac{G_{0} \sqrt{\frac{\sigma_{v}^{\prime}}{\sigma_{v 0}^{\prime}}}}{1+\frac{\gamma_{\text {eff }}}{\gamma_{r}} \sqrt{\frac{\sigma_{v 0}^{\prime}}{\sigma_{v}^{\prime}}}}
$$

となる.ここに， $\sigma_{v 0}^{\prime}$ は初期鉛直有効态力である. 式 (13) は, 初期剛性率と規準ひずみがともに有効応力の低下率 の平方根に比例して低下していくことを示している.

等価線形解析における運動方程式は式（7）と同じで あるが，応力・ひずみ関係が直線となりループを描かな いために夏歴減衰は存在しない，そこで，本解析による 結果を非線形解析による結果と対応させるためには，履 歴减衰による減衰量を粘性減衰項で表わすことが必要て ある。粘性減衰項における減衰マトリックスは, Rayleigh 型とし，次式によった。

$$
\boldsymbol{C}=h \omega_{1} \boldsymbol{M}+\frac{h}{\omega_{1}} \boldsymbol{K}
$$

ここに， $\omega_{1}$ は地盤の 1 次の固有円振動数であり, 有効 応力の変化に伴い変動する。减衰定数は, Hardin Drnevich モデルにおける履歴減衰を表わす次式 ${ }^{161} よ り$ 求めた.

$$
h=\frac{4}{\pi}\left[\frac{G_{0}^{\prime}}{G_{\text {current }}}\left\{\frac{\gamma_{r}^{\prime}}{\gamma_{\text {eff }}}-\left(\frac{\gamma_{r}^{\prime}}{\gamma_{\text {eff }}}\right)^{2} \cdot \ln \left(1+\frac{\gamma_{\text {eff }}}{\gamma_{r}^{\prime}}\right)\right\}-\frac{1}{2}\right]
$$

$$
\text { ここで, } G_{0}^{\prime}=G_{0} \sqrt{\sigma_{v}^{\prime} / \sigma_{v 0}^{\prime}}, \quad \gamma_{r}^{\prime}=\gamma_{\tau} \sqrt{\sigma_{v}^{\prime} / \sigma_{v 0}^{\prime}} \text { であり, }
$$
有効応力の変化により式中 $G_{0}^{\prime}, G_{\text {current }}, \gamma_{r}^{\prime}$ が変動する.

本法による解析手順をまとめると, 図一6のフロー チャートのようになる. 図の左半分は, 既往の全応力法 そのものである.これは，有効応力解析のための初期定 数を決定するだけのものであるから, 応答解析は, 時間, 周波数のいずれの領域で行ってもよい．続く有効応力解 析では時系列の応答解析が必要であるが, 非線形解析と 異なり定数の修正は応力波形の半サイクルごとでよいこ 
とになる.この分の演算の節約が本法の利点である.

\section{5. 解析結果}

\section{(1) 1 次元問題}

上述の有効忘力法を用いて 1 次元問題の解析を行っ た. 解析は, 非線形, 等価線形の両解析をともに行った。 等価線形解析は, 非線形解析の簡便法ではあるが，これ まで全応力法において, 非線形解析とは多少異なった結 果を与えることが指摘されてきだ7)。それは，等価線形 解析の場合, 全応答過程において地盤の動的定数をある ひずみレベルに着目して一定なものとみなしてしまうの で，入力の南特定の周波数成分との反応を強めるため と考えられる.

そこで，ここに提案する等価線形有効応力解析が，亡゙ の程度非線形有効応力解析を近似できるか調べてみる必 要があると思われる．等価線形解析では，ランダム波の 適用に対して，まず全応答過程を代表する有効せん断ひ ずみ $\gamma_{\mathrm{eff}}$ が決定される。これは，応答せん断ひずみレべ ルに応じた定数の決定に必要であり, 通常, 最大せん断 ひずみに係数を掛けた形で表わされている。すすおち，

$$
\gamma_{\mathrm{eff}}=\alpha \gamma_{\max }
$$

係数 $\alpha$ は, ひずみ低減係数と呼ばれるもので, 全応力 法では 0.65 とする場合が多い。この有効せん断ひずみ の大きさすなわち $\alpha$ の值のとり方によって応答に違い が生じ, 非線形解析結果ともかなりの差が生じることが 知られている ${ }^{18}$ が，実際にはほとんど検討がなされない まま解析が行われている. 本法では, 図一6のフロー チャートに示すように，有効せん断ひずみを全応力法で 求め, これをそのまま有効応力法に適用するので, 有効
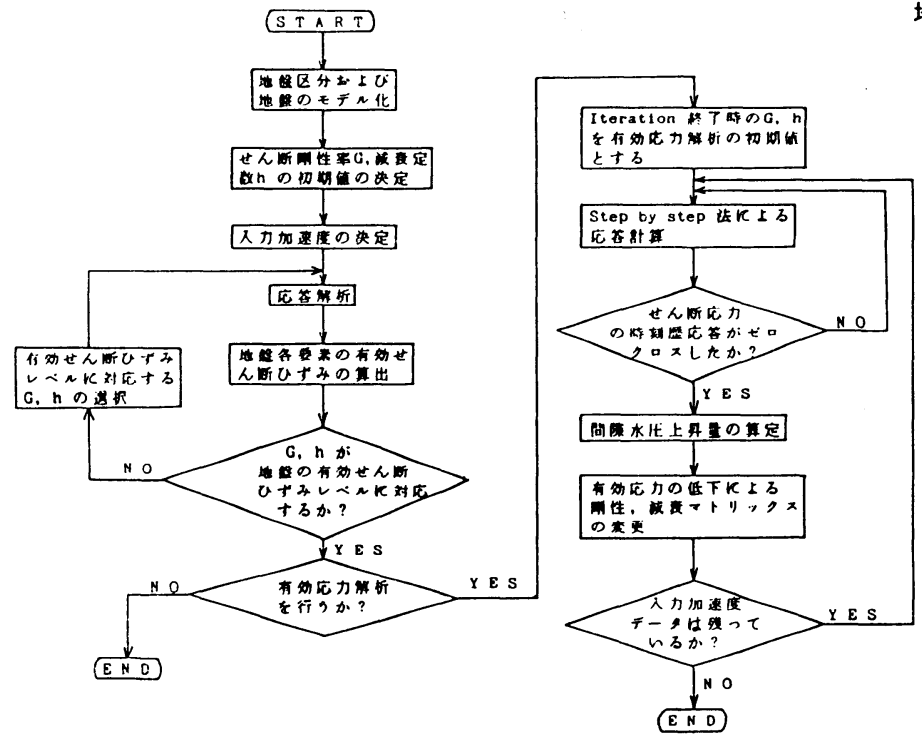

図一6等価線形有効応力解析法のフローチャート

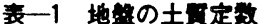

\begin{tabular}{c|c|c|c|c}
\hline$G_{s}$ & $e$ & $D_{r}$ & $K_{\bullet}$ & $\phi$ \\
\hline 2.65 & 0.80 & $50 \%$ & 0.5 & $35^{\circ}$ \\
\hline
\end{tabular}

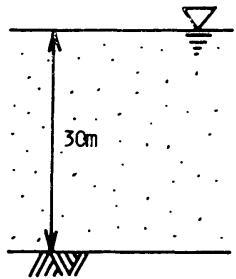

図一7 䭒和砂水平地艋

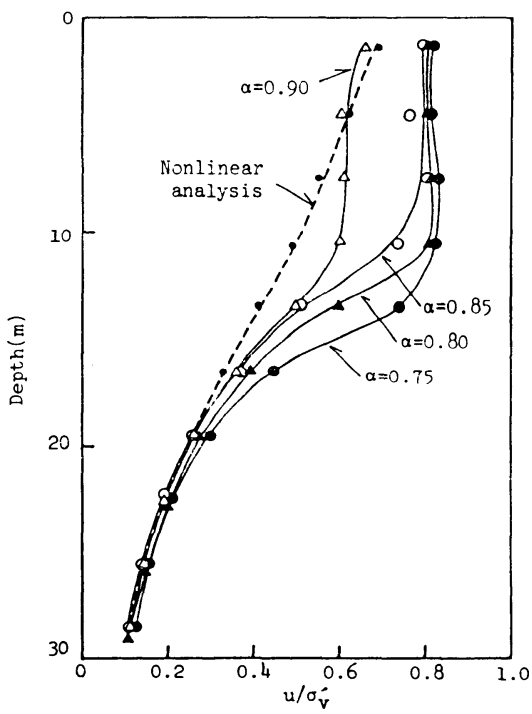

図一8 非線形および等価線形解析による间除水圧の 地中分布 $\left(a_{\max }=0.1 \mathrm{~g}\right)$

せん断ひずみのとり方について検討を加 えてみたい。ここでは非線形解析結果と 比較して, 式（16）中の $\alpha$ の值を調節 してみる。

解析対象地盤として, 図一7に示す厚 さ $30 \mathrm{~m}$ の均質な飽和砂地盤を想定す る. 地盤の物性值は表一1のとおりとす る. 入力波として, El Centro (1940) 波 N-S 成分を最大值 $0.05 \mathrm{~g}, 0.1 \mathrm{~g}$, $0.15 \mathrm{~g}$ に縮小したものをそれぞれ 20 秒 間入射した。

図一8は，最大値 $0.1 \mathrm{~g}$ の波を入射し た場合の地盤内の間隙水圧上昇量の深さ 方向分布を表わしている. 図中, 実線が 等価線形解析による結果であり, 破線は 非線形解析によるものである，等価線形 


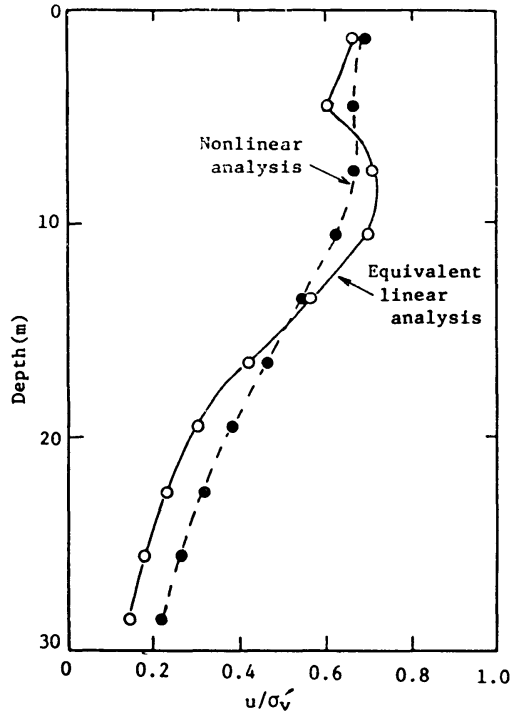

(a) $a_{\max }=0.15 \mathrm{~g}$

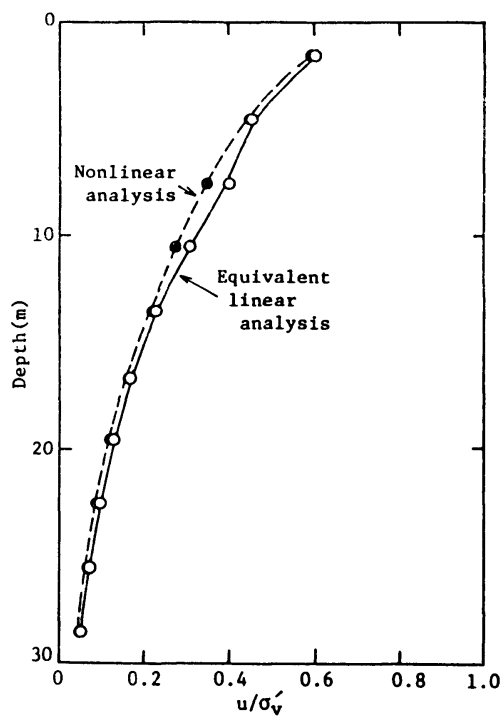

(b) $a_{\max }=0.05 \mathrm{~g}$

図一9 間隙水圧の地中分布

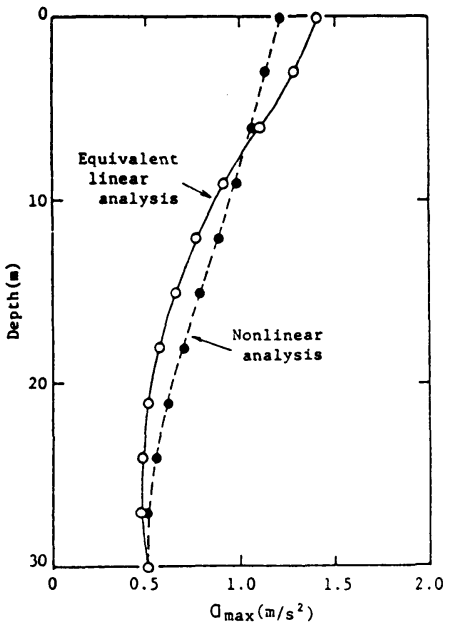

(a) $a_{\max }=0.05 \mathrm{~g}$

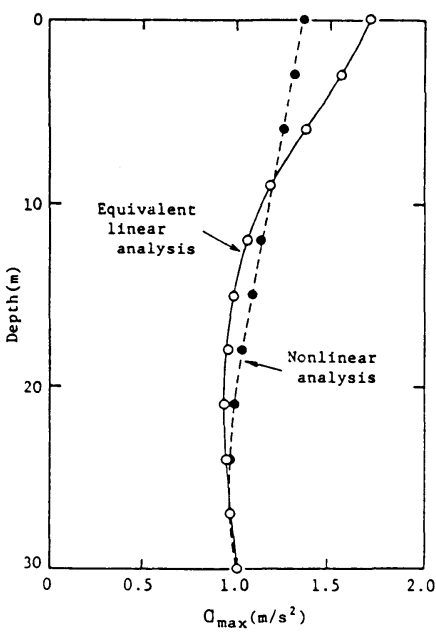

(b) $a_{\max }=0.1 \mathrm{~g}$

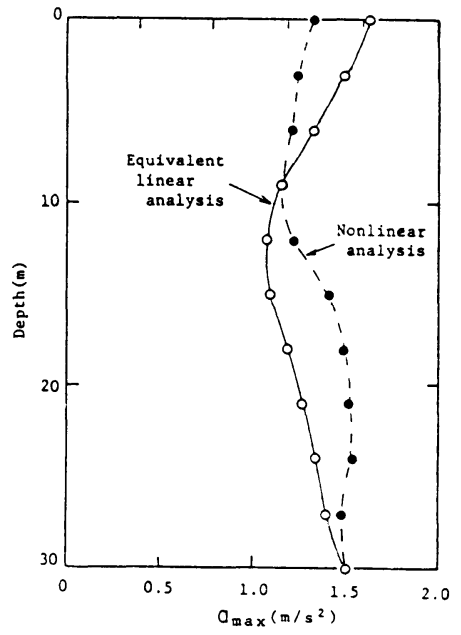

(c) $a_{\max }=0.15 \mathrm{~g}$

図一10 最大応答加速度の地中分布

解析結果は式（16）で表わされる有効せん断ひずみを, $\boldsymbol{\alpha}$ の值を変えることにより変化させたものである. 図の ように, $\alpha$ の值の違いにより間隙水圧の上昇傾向はかな り異なり， $\alpha$ が大きくなるほど間隙水圧の上昇量は低下 する傾向がみられる. 非線形解析の結果と比較してみる と $\alpha=0.9$ の場合に両解析法による結果は比較的近いよ うである。

図一9に，最大値 $0.05 \mathrm{~g} と 0.15 \mathrm{~g}$ の波を入射した場 合の最終的な間隙水圧上昇量の深さ分布が示されてい る. いずれも等価線形解析は $\alpha=0.9$ としたときの結果 であり, 非線形解析の結果とかなりよく一致しているこ
とが認められる，上記の結果もあわせると，両解析法に よる結果は入力レベルの違いにもかかわらず比較的よく 一致することがいえるようである。このように，本解析 ケースについては, 間隙水圧の上昇量において, $\alpha=$ 0.9 とした場合の等価線形解析結果は, 非線形解析結果 を近似できるものと考え, 以下 $\alpha=0.9$ の場合について 取り扱う。

図一10，11に，最大応答加速度および最大せん断応 力の梁さ分布がそれぞれ示されている.いずれも入力最 大値 $0.05 \mathrm{~g}, 0.1 \mathrm{~g}, 0.15 \mathrm{~g}$ のそれぞれの解析結果が記 されているが．等価線形解析の結果は非線形解析の結果 


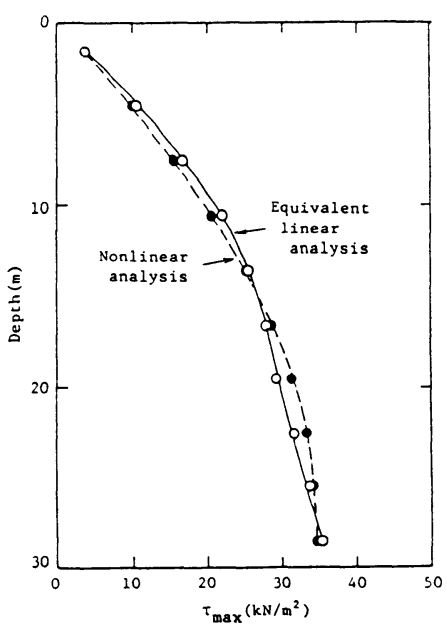

(a) $a_{\max }=0.05 \mathrm{~g}$

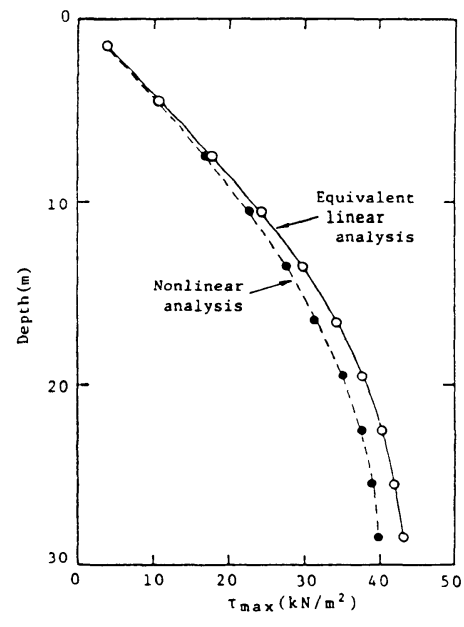

(b) $a_{\max }=0.1 \mathrm{~g}$

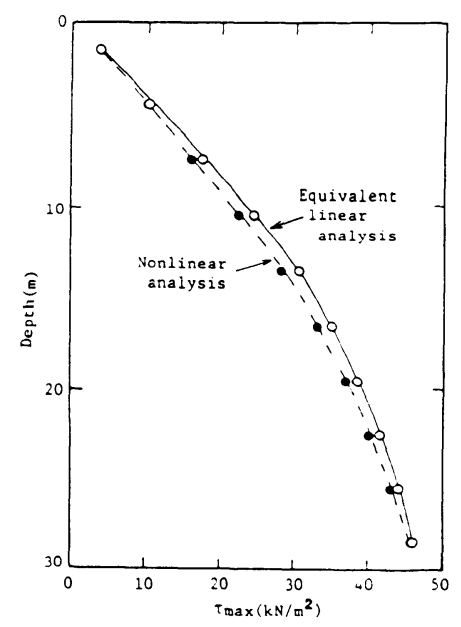

(c) $a_{\max }=0.15 \mathrm{~g}$

図一11最大心答せん断応力の地中分布

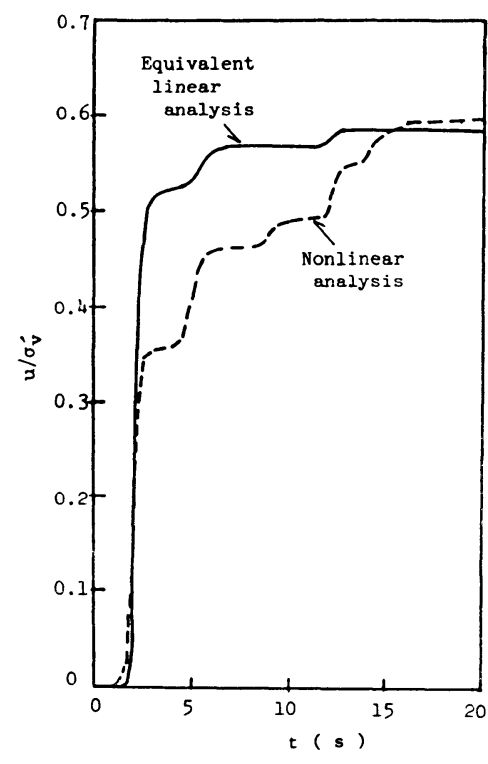

図一12 表首最上雷における間隙水圧の 時間変化 $\left(a_{\max }=0.05 \bar{g}\right)$

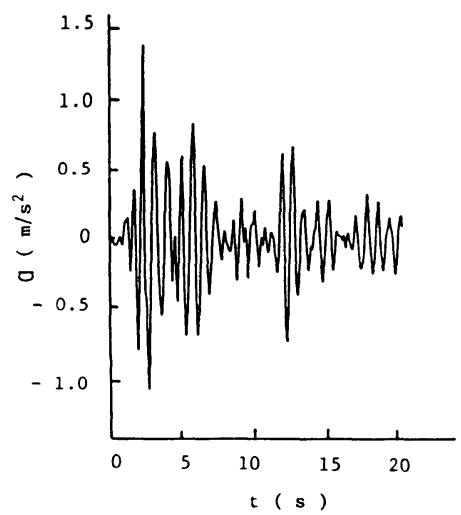

（a）等価線形解析

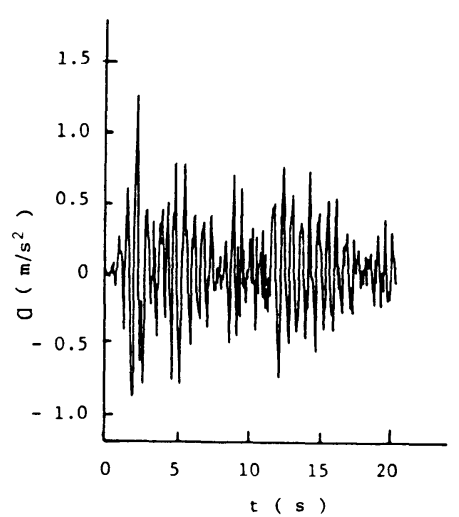

(b) 非線形解析

図一13 地表面応答加速度の時刻歴 $\left(a_{\text {max }}=0.05 \bar{g}\right)$

とかなりよく一致している．以上は応答の最大值につい ての記述であるが，次に応答の時刻歴について調べてみ る.

図一12 は，表層地盤最上層における間隙水圧上昇量 の時間的変化を表わしたものである．等価線形解析と非 線形解析の結果を比較すると，前者の場合，間隙水圧が ある時刻で急上昇する形であるのに対し，後者の場合は 徐々に増加していく傾向が認められる.最終的には両者 の結果はほぼ等しくなるが, 途中ではかなり異なってい る.
図一13には，地表面における応答加速度の時刻歴が 示されている，等価線形解析における応答波形は, 非線 形解析のそれに比へ，全体的になめらかなのが特徵的で ある. また, 最大値は等価線形解析による方が大きいが, 時間の経過に伴う応答の低下も激しいようである。これ は, 等価線形解析においては地盤系の固有振動数が一義 的に定まり，初期には入力波の特定の周波数成分が増幅 されるが，有効応力の減少に伴い固有振動数の低下が生 じしだいに入力波の増愊される成分が少なくなるため と考えられる. 


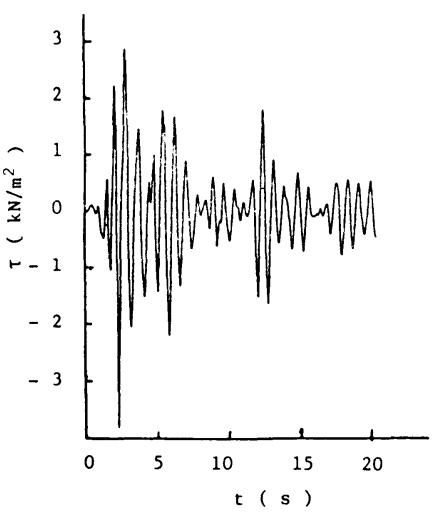

(a) 等価線形解析

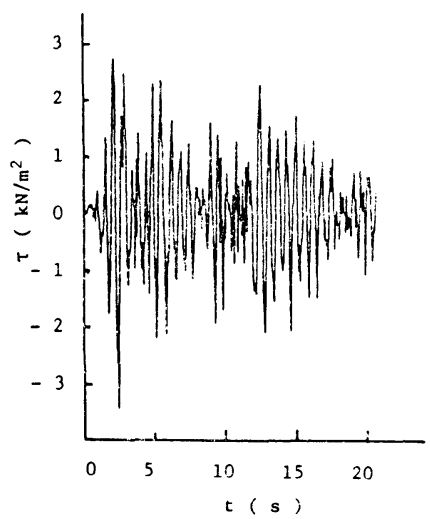

(b) 非線形解析

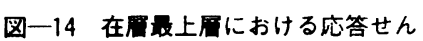
断応力の時刻歴

$\left(a_{\max }=0.05 \mathrm{~g}\right)$

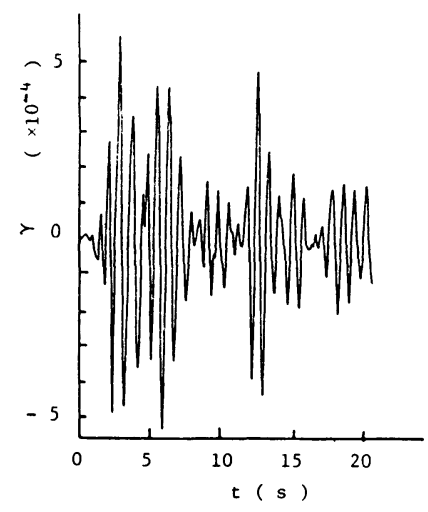

(a) 等価線形解折

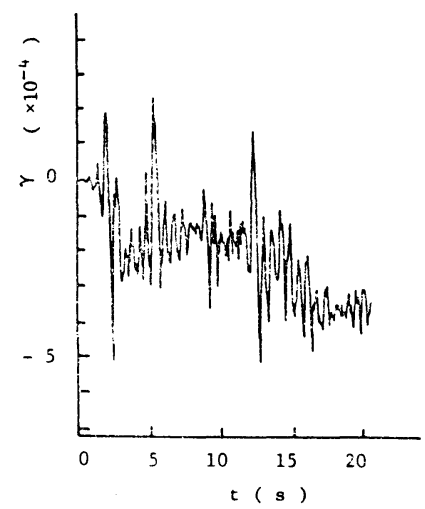

(b) 非線形解析

図一15表居最上屋における応答せん 断ひずみの時刻歷

$\left(a_{\max }=0.05 \mathrm{~g}\right)$

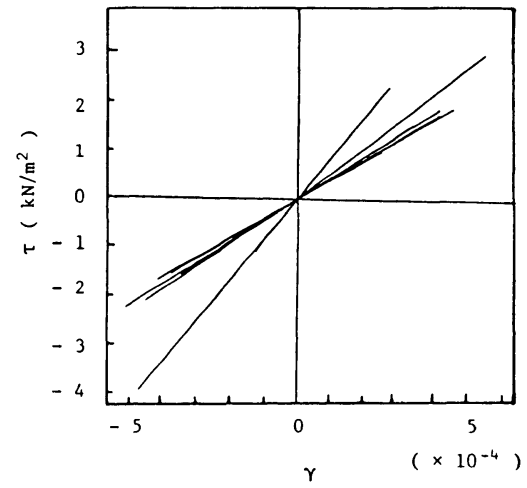

（a）等価線形解析

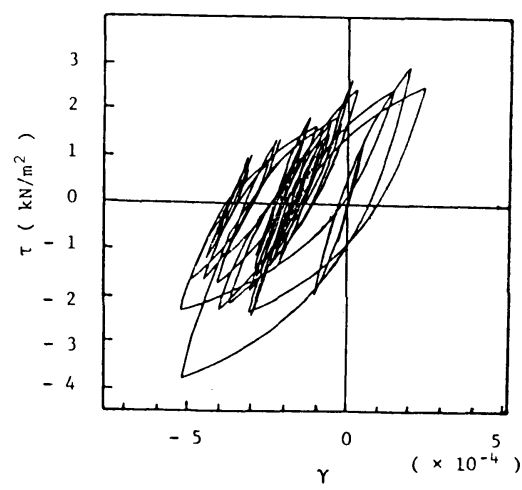

(b) 非線形解析

图一16 表届最上屈における応力・ひずみ関係 $\left(a_{\max }=0.05 \mathrm{~g}\right)$
図一14，15は，最上層のせん断応力とせん断ひずみ の時刻歴をそれぞれ示したものである。せん断応力の応 答結果は加速度応答亡ほぼ同一の傾向を示している。せ ん断ひずみは, 加速度, せん断応力と異なり有効応力の 低下によって減衰せず，むしろ最終時刻付近でも大きな 振幅を有している.また，せん断ひずみの応答は，等価 線形解析においては原点を通る水平軸を中心に振動して いるが，非線形解析では片側に残留ひずみが現われてい る.この相違は, 等価線形解析の応力・ひずみ関係が原 点を通る直線で表わされているのに対し，非線形解析で は半サイクルごとの有効応力と㣚性の低下に伴い, 正負 両側の甘ん断応力の総計がかなり異なってくるためと考 えられる。

図一16には，最上層における両解析法による応力・ ひずみ関係が描かれている，等価線形解析の場合は，原 点を通る直線の勾配がしだいに緩くなる形で用性の低下 の様相か現われている. 非線形解析の方は, ループの形 がしだいに変化してゆき, 残留ひずみが生じた分片側に
移行する形になっている.

以上の結果から，等価線形解析法による応答結果は, 時刻歴においては非線形解析の結果と若干の相違がみら れるが, 応答の最大值, 間隙水圧の最終值はよく一致す ることが認められる。ただし，この場合適切な有効ひす みの設定が必要である。

本解析では数值積分は, 非線形, 等価線形の両解析之 もに Newmark $\beta$ 法 $(\beta=1 / 4)$ によった。この方法は陰 解法であるから, 時間刻みは比較的粗くてもよいが逆マ トリックスの計算を必要とし，ここで多くの時間を消費 する．等価線形解析においては，各時間ステップでの逆 マトリックスの演算が不要となり応力の半サイクルごと にある程度の間隙水圧の変動が生じたときのみ行えばよ いことになる．このように，非線形解析に比べ，かなり の計算時間の短縮が可能である.

\section{（2） 2 次元問䫝}

等価線形解析法を用いてより自由度の高い 2 次元の有 限要素解析を行った。解析対象は，図一17に示される 
杭・地盤系である.ここでは, 5. (1) と同じ水平地盤 に杭が打設された場合を想定しており，地盤の物性は表 一1と同じである. 杭は, 先端が基盤に剛結され上部に フーチングを有する支持杭である.フーチングの重量は すべて杭が支持するものと仮定すると，このような条件 下では地盤の初期条件は 5.（1）と同じ $K_{0}$ 状態と考え ることができる。これに水平方向の地震外力を考えた場 合, 応力状態のとらえ方は5.（1）と同様に取り扱うこ とができる.

杭は, 直径が $1 \mathrm{~m}$ でヤング率 $E=2.36 \times 10^{7} \mathrm{kN} / \mathrm{m}^{2}$,

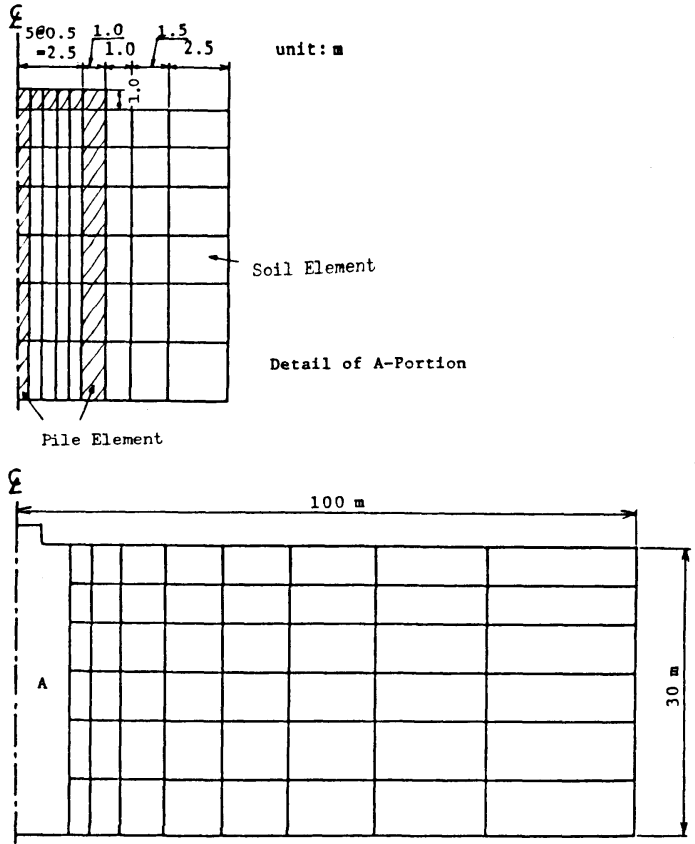

General Side Section 図一17杭・地盤系要素図

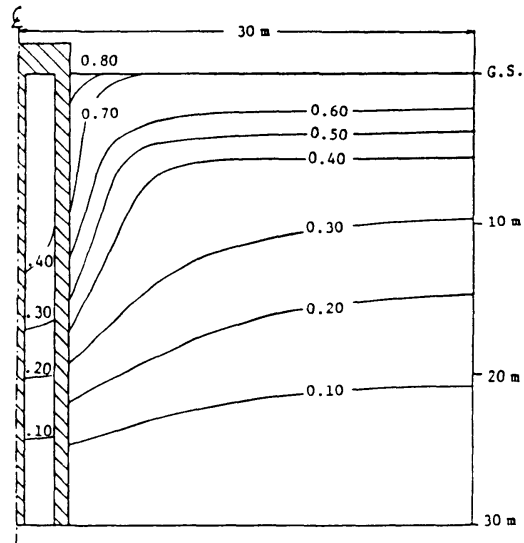

図一18 杭周辺地盤における $u / \sigma_{v}^{\prime}$ の分布状況
ポアソン比 $\nu=0.25$, 密度 $\rho=3.10 \mathrm{t} / \mathrm{m}^{3}$ の物性をもつ 材料とし, 水平，奥行き方向に $2 \mathrm{~m}$ 間隔で各 3 本，計 9 本が配置されている，なお，杭のヤング率は，奥行き 方向の配置を考虑して $1 / 3$ に低下させた，人力波は El Centro 波を最大值 $0.1 \mathrm{~g}$ に調整し，0.02 秒刻みで基盤 より 10 秒間加えた。数值積分はNewmark $\beta$ 法 $(\beta=1 / 4)$ によった。このような条件で杭・地盤系の解析を行い, ここでは，間隙水圧上舁に及ぼす杭の影響について調へ てみた。

解析領域は, 中心線より画側に $100 \mathrm{~m}$ が設けられて いるが，この条件では杭周辺 30〜 $40 \mathrm{~m}$ の範囲では境界 の影響が現われないことがまず確認された。図一18は， 杭周辺地盤の間隙水圧上昇量の分布を示したものであ る. 杭の存在により，杭近傍において間隙水圧の分布形 状に顕著な変化が認められる。また，杭近傍でも群杭の 外側と内側ではその様相は異なっている，杭の外側では 間隙水圧のコンターが下部へ食い込み間隙水圧が高く出 ているのに対し，杭間では他の部分に比べかなり低い水 圧値である。すなわち，間隙水圧上昇に及ぼす杭の影響 は，杭外側で水圧上并が促進され，杭間では逆に㧕止さ 机る形として現わ机るようである。この結果は，本解析 ケースの結果であり，一般論として言及することはでき ないが，少なくとも地盤内の間隙水圧上昇に対して，杭 基礎等地中構造物の影響が現われることは事実のようで ある。やはり，構造物を含めた地盤の有効応力解析が必 要なことは当然であるが，その際，かなり自由度の多い 問題も出てくるものと考えられる。ここで提案する等価 線形有効忍力解析法を用いると，計算時間の大幅な短縮 化が叮能である。

\section{6. 結 論}

本研究は，地祳時に方ける飽和砂地盤の有効志力解析 法の簡易化を日指して行ったものである。これまでの有 効応力解析法が，必ずしも実用的ととらえられ得ない原 因の中に，用いられる構成式の適用上の問題と非線形の 運動方程式を解析する際の膨大な計算量があると思われ る.ここでは, 間隙水圧上昇量の評価法として, 現状最 もなじみが深くデータ量も豊富なSeed 式を用いた。さ らに，計算時間の短縮化をはかるために，等価線形有効 応力解析法の提案を行った。この解析法による結果の精 度は, 非線形有効応力解析結果と比較することによって 検証された。 1 次元および 2 次元問題を対象とした具体 的な数値計算の結果, 以下の事項が明らかとなった。

（1）等価線形有効応力解析法は, 適切な有効せん断 ひずみ量を与えることにより，応答加速度，せん断応力 の最大値および間陌水圧上昇量の最終値などで，非線形 解析法を近似できる。 
（2）等価線形解析による応答の時刻歴は, 非線形解 析結果に比べると全体的に波形がなめらかであり，特定 の周波数成分が選択された様子か認められる．等価線形 解析による加速度, せん断応力の波形は, 最大值は大き く現われるが，間隙水圧の上昇に伴い，減衰していく傾 向も顥著である。

（3）杭・地盤系の 2 次元問題を解析することによ り，杭近傍の地盤が特異な間隙水圧分布を呈すことが認 められた。すすなわち，間隙水圧上昇に及ぼす杭の影響が 現われ，杭外側で水圧上昇が促進され，杭間では逆に抑 止される結果が得られた。

\section{参考文献}

1) Seed, H. B. and Idriss, I. M. : Analysis of soil liquefaction : Niigata earthquake, Proc. ASCE, Vol. 93, No. SM 3, pp. 83 108, 1967.

2) Lee, K. L. and Chan, K. : Number of equivalent significant cycles in strong motion earthquakes, Proc. International Conference on Microzonation for Safer Construction Research and Application, pp. 609 627, 1972.

3) Seed, H. B. and Idriss, I. M. : Simplified procedure for evaluating soil liquefaction potential, Proc. ASCE, Vol. 97, No. SM9, pp. 1249 1273, 1971.

4) Lee, K. L. and Focht, J. A., Jr. : Liquefaction potential at the Ekoffisk Tank in the North Sea, Proc. ASCE, Vol. 101, No. GT1, pp. 1 18, 1975.

5) 日本道路協会：道路橋示方書 - 同解説 V. 耐震設計編, pp. $16 \sim 22,1980$.

6) Finn, W. D. L., Lee, K. W. and Martin, G. R. : An effective stress model for liquefaction, Proc. ASCE, Vol. 103, No. GT6, pp. 517 533, 1977.

7) Ghaboussi, J. and Dikmen, U.S. : Liquefaction analysis of horizontally layered sands, Proc. ASCE, Vol. 104, No. GT3, pp. 341 357, 1978.
8) Zienkıewicz, O.C., Chang, C. T. and Hinton, E. : Non-linear selsmic response and liquefaction, Int. Jour. for Numerical and Analytical Methods in Geomechanics, Vol. 2, pp. 381 404, 1978.

9）石原研而・東畑郁生：動的間隙水圧を考慮した地盤の応 答解析, 第 14 回土質工学研究発表会講演集, pp. 1305 $1308,1979$.

10）紫田 徹・佐藤忠信 - 小坂正明：砂地盤の液状化解析例, 第 14 回土質工学研究発表会講演集, pp. 1313 1316, 1979 .

11) Hardin, B. O. and Drnevich, V.P. : Shear modulus and damping in soils : Design equations and curves, Proc. ASCE, Vol. 98, No. SM7, pp. 667 691, 1972.

12) Richart, F.E., Hall, J. R. and wood, R. D. : Vibrations of soil foundations, Prentice-Hall, Inc., Englewood Cliffs, New Jersey, 1970.

13) Seed, H. B., Martin, P.P. and Lysmer, J. : Porewater pressure changes during soil liquefaction, Proc. ASCE, Vol. 102, No. GT 4, pp. 323 346, 1976.

14) Tatsuoka, F., Muramatsu, M. and Sasaki, T. : Cyclic undrained stress strain behavior of dense sands by torsional simple shear test, Soils and Foundations, Vol. 22, No. 2, pp. 55 70, 1982.

15) Seed, H. B. and Booker, J. R. : Stabilization of potentially liquefiable sand deposits using gravel drains, Proc. ASCE, Vol. 103, No. GT 7, pp. 757 768, 1977 .

16）国生剛治・桜井彰雄：Modified Hardin-Drnevich モデル

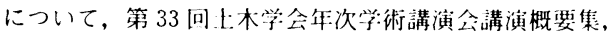
III, pp. 253 254, 1978.

17）藤野陽三・伯野元彦：地盤の非線形性を考虑した地霞動 特性, 上木学会論文報算集, 第 240 品, pp. 1 9, 1975.

18) Bieber, R.E. and Hovland. H. J. : Seismic dynamic response by approximate methods, Proc. Earthquake Engineering and Structual Dynamics, Vol.8, pp.41 53, 1980.

(1983.8.22 • 受付) 